\title{
Second Generation Bioethanol Production Process Via Catalyzed Steam Explosion Pretreatment: A Computer-aided Exergy Analysis and Heat Integration
}

\author{
K. Ojeda-Delgado ${ }^{*}$, Á. D. González-Delgado² and E. Sánchez-Tuirán ${ }^{1}$ \\ 'Department of Chemical Engineering, Process Design and Biomass Utilization Research Group (IDAB), University of \\ Cartagena, Cartagena, Bolívar, Colombia; kojedad@unicartagena.edu.co, esanchezt2@unicartagena.edu.co \\ 2Department of Chemical Engineering, Nano materials and Computer Aided Process Engineering Research Group \\ (NIPAC), University of Cartagena, Cartagena, Bolívar, Colombia; agonzalezd1@unicartagena.edu.co
}

\begin{abstract}
Background: Bioethanol is one of the most important biofuels because it has been produced from residual biomass such as corn stover, sugarcane bagasse, agricultural waste, among others. Bioethanol production from non-food biomass represents an opportunity for the biofuels industry to use raw materials in countries with high agricultural development, providing new alternatives for increasing the global production of biofuels. Therefore, process technologies have to be analyzed in order to guarantee the real energy gain in the biofuels industry through exergy analysis and computer-aided system engineering. Objectives: In this work, exergy analysis and heat integration methodologies were applied to evaluate hydrolysis and fermentation technologies when steam explosion pretreatment was used as pathway. Methods/Analysis: Bagasse from sugar industry was considered as raw material for bioethanol production. This residual lignocellulosic biomass was pretreated through catalyzed steam explosion and sent to different process configurations such as Separated Hydrolysis and Fermentation (SHF), Simultaneous Saccharification and Fermentation (SSF), and Simultaneous Saccharification and Co-Fermentation (SSCF). The three processes were analyzed using exergy analysis criteria and the best alternative was integrated to reduce heating and cooling utilities in the process and to improve the energy profile for the bioethanol process. Findings: It was found that the highest exergy efficient was obtained when SSCF technology was used after catalyzed steam explosion pretreatment in comparison with SHF and SSF alternatives. Application of heat integration methodologies reduced cooling utilities by $57.7 \%$ and heating utilities by $63.4 \%$. Novelty/Improvement: Implementation of computer-aided process, heat integration and exergy analysis allowed to compare and evaluate bioethanol technologies in order to reduce the energy requirements for the biofuel process and increase the net energy gain.
\end{abstract}

Keywords: Bioethanol, Catalyzed Steam Explosion, Exergy, Heat Integration, Hydrolysis

\section{Introduction}

The major concern in the fuel industry is related to the stock of fossil energy which are decreasing continually ${ }^{1}$. Hence, most countries have begun to opt for green alternatives such as biofuels's. Biomass is one of the best candidates to meet the current and upcoming fuel demand ${ }^{3}$. Different kind of liquid and gaseous fuels can be produced from residual biomass such as corn, wheat, straw and wood, among others ${ }^{4}$. Bioethanol is a biofuel widely used in transport sector ${ }^{5}$; it can be obtained from lignocellulosic biomass that could be obtained from corn, residual crops, agro-industrial wastes, and among others $^{6}$, in a sustainable way ${ }^{7}$. The bioethanol is mainly

${ }^{*}$ Author for correspondence 
produced from sugarcane, corn and sugar beet in Brazil, United States and Europe, respectively ${ }^{8}$. Bioethanol from lignocellulosic material has the benefit of increasing the efficient use of arable land by taking greater advantage of the overall biomass generated in agricultural processes, therefore greater benefits are obtained in terms of sustainability 9 . The quality of bioethanol produced is majorly dependent on the production routes, which also affects overall production costs, therefore, a variety of production alternatives have been proposed for the bioethanol process $^{10}$. However, there is no agreement whether these alternatives are the most adequate for the industrial-scale implementation which generates difficulties when selecting technologies for the industrial sector. Hence, it is necessary to develop an analysis methodology that allows the comparison and selection of technological schemes considering energy aspects.

\section{Material and Methods}

\subsection{Analytic Methodology based on Exergy}

Analytic hierarchy methodologies based on economic and environmental issues have been used as tool for process evaluation ${ }^{11}$. However, for biofuels industry, specific economic and environmental analysis need to be performed complemented with energy analysis in order to verify the net energy value for the biofuel produced. Most of the bioethanol process topologies have to be evaluated in an energy context therefore; exergy analysis is an important tool to identify the exergy efficiency, exergy emissions and irreversibilities for the process. The hierarchy methodology based on exergy analysis and heat integration strategies used in this work is shown in Figure 1.

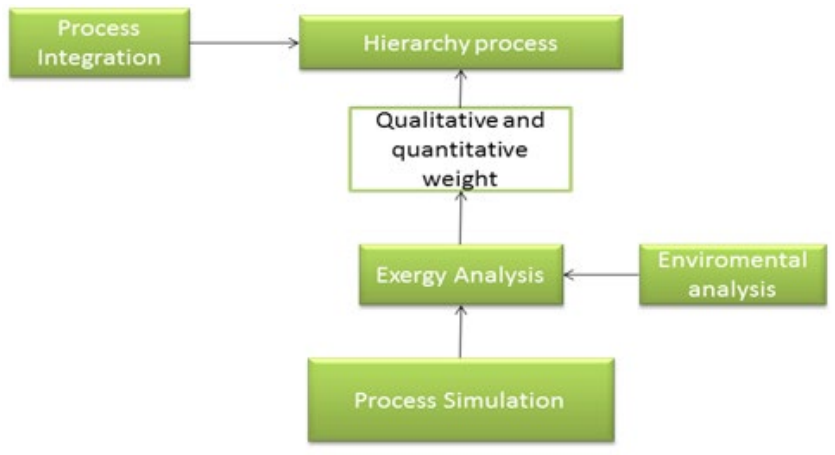

Figure 1. Analytic hierarchy process based on exergy.
Recent researches in the field of PSE have been based on the approach of methods to reach the sustainable development of the systems. The sustainability and renewability of an energy source is hard to quantify ${ }^{12}$, integral analysis based on economic, environmental, and energy profile of the bioethanol process must be performed. Although an environmental analysis gives qualitative evaluations of the environmental impacts caused by the use of energy sources, the weight given in a subjective approach makes the results questionable. On the other hand, the exergy gives an opportunity to unify measurements of different kind of materials and energies and also evaluates the quality of the products and their degradation on the conversion processes ${ }^{13}$.

The quantification of thermodynamic exergy can be used to evaluate and improve the production processes by means of a better understanding of the benefits of renewable energies. The exergy clearly identifies the improvements in the efficiency and the reductions on the energy losses related with the technology used. Exergy analysis has been applied to second generation biofuels. $\operatorname{In}^{14}$ analyzed the production of ethanol from banana using both exergy and renewability analysis. $\operatorname{In}^{15}$ compared the production of ethanol from palm fruits using exergy analysis. Some articles have been published in this topic ${ }^{16-19}$. The exergy analysis methodology allows identifying pathways and stages with the higher exergetic consumption allows selecting the most feasible design for the bioethanol production.

\section{Results and Discussion}

A case study using 1,200 t/day of sugarcane bagasse was simulated considering catalyzed steam explosion as pretreatment stage. The pretreatment stage was carried out using $\mathrm{H}_{2} \mathrm{SO}_{4}$ and high-pressure saturated steam $(461 \mathrm{~K}$, $0.6 \mathrm{MPa})$. The simulated processes considered three bioethanol production topologies (SHF, SSF, and SSCF) ${ }^{20}$ followed by the bioethanol purification stage. Figure 2 shows pretreatment process carried out to sugarcane bagasse.

The pretreated biomass was washed and sent to the hydrolysis and fermentation stages: SHF, SSF, and SSCF, respectively. The SHF technology was simulated using the following characteristics: Saccharification $(101.325 \mathrm{kPa}$, $321 \mathrm{~K})$, Fermentation (101.325 kPa, $303 \mathrm{~K})$, Cellulase enzyme: $18 \mathrm{FPU} / \mathrm{g}$ cellulose -Microorganism: S. cere- 


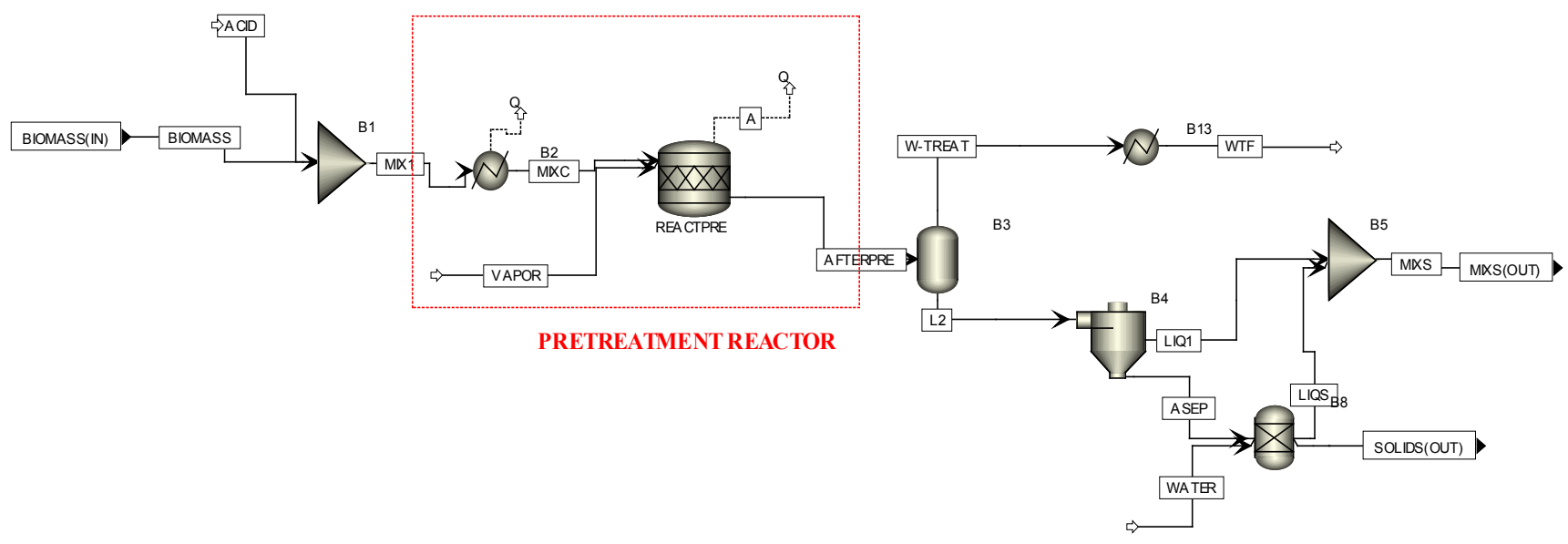

Figure 2. Pretreatment process.

visiae $^{11}$. SSF stage was simulated $(101.325 \mathrm{kPa}, 308 \mathrm{~K})$; Enzyme cellulase $20 \mathrm{FPU} / \mathrm{g}$ cellulose; Microorganism: $S$. cerevisiae $^{21}$. For the SSCF: (101.325 kPa, $\left.314 \mathrm{~K}\right)$, Cellulase Enzyme $15 \mathrm{FPU} / \mathrm{g}$ Cellulose - Z. mobilis ${ }^{21}$ with a conversion of glucose to ethanol of $92 \%$ and a conversion of xylose to ethanol $85 \%$. Table 1 summarizes main information for the cases studies.

All processes were analyzed and compared using exergy results. The process schemes were divided in the main stages to identify irreversibilities, exergy efficiency and environmental impact based on exergy emissions. Exergy Flows for SHF, SSF and SSCF processes are presented in Tables 2-4, respectively.

Exergy analysis results are shown in Figure 3, which indicated that the highest irreversibilities are in the SHF stage $(40 \mathrm{MJ} / \mathrm{kg}$ ethanol). The use of separate hydrolysis and fermentation technologies generates greater inhibitory effects in the reaction systems, which increases the

Table 1. Main conditions for the cases studies

\begin{tabular}{|c|c|c|}
\hline & Characteristic & Value \\
\hline \multirow{3}{*}{ Biomass } & Raw Material & Sugacane bagasse \\
\hline & Composition & $\begin{array}{l}\text { Cellulose } 23 \% \text {, Hemicellulose } 11 \% \\
\text { Lignin } 13.5 \% \text {, Ash 2.5\%, moisture 50\% }\end{array}$ \\
\hline & Mass Flow & 1200 t/day \\
\hline \multirow{3}{*}{ Pretreatment } & Pretreatment & $\mathrm{H}_{2} \mathrm{SO}_{4}$ catalyzed steam explosion $(2.25 \%)$ \\
\hline & Temperature & $461 \mathrm{~K}$ \\
\hline & Solids & $13 \%$ \\
\hline \multirow{3}{*}{ SHF } & Cellulose degradation & $75 \%$ \\
\hline & Produced Ethanol & $5452.01 \mathrm{~kg} / \mathrm{h}$ \\
\hline & Composition & 99\% (Molecular sieves) \\
\hline \multirow{3}{*}{ SSF } & Cellulose degradation & $80 \%$ \\
\hline & Produced Ethanol & $5858.51 \mathrm{~kg} / \mathrm{h}$ \\
\hline & Composition & 99\% (Molecular sieves) \\
\hline \multirow{3}{*}{ SSCF } & Cellulose degradation & $88 \%$ \\
\hline & Produced Ethanol & $6099.62 \mathrm{~kg} / \mathrm{h}$ \\
\hline & Composition & 99\% (Molecular sieves) \\
\hline
\end{tabular}




\begin{tabular}{|l|l|l|l|l|l|}
\hline Table 2. Exergy flows for SHF process \\
\hline & Pretreatment & Saccharification & Fermentation & $\begin{array}{l}\text { Pentose fermentation } \\
\text { + Neutralization }\end{array}$ & Purification \\
\hline Exergy input - Flow (MJ/h) & $562,307.89$ & $474,148.45$ & $170,434.58$ & $59,972.21$ & $188,404.62$ \\
\hline Exergy output - Flow (MJ/h) & $534,659.88$ & $427,356.25$ & $169,154.37$ & $55,546.84$ & $186,789.15$ \\
\hline Exergy - Q (MJ/h) output & $23,059.80$ & $1,178.07$ & 144.49 & 361.38 & $25,053.95$ \\
\hline Exergy - Q (MJ/h) input & $40,533.96$ & 504.85 & & 28.22 & $39,265.67$ \\
\hline
\end{tabular}

Table 3. Exergy Flows for SSF process

\begin{tabular}{|l|l|l|l|l|}
\hline & Pretreatment & SSF & $\begin{array}{l}\text { Pentose fermentation } \\
\text { + Neutralization }\end{array}$ & Purification \\
\hline Exergy input - Flow (MJ/h) & $562,307.89$ & $324,683.26$ & $59,972.21$ & $191,428.48$ \\
\hline Exergy output - Flow (MJ/h) & $534,659.88$ & $310,638.30$ & $55,546.84$ & $192,750.11$ \\
\hline Exergy - Q (MJ/h) output & $23,059.80$ & $2,121.88$ & 361.38 & $26,509.34$ \\
\hline Exergy - Q (MJ/h) input & $40,533.96$ & 507.00 & 28.22 & $41,288.53$ \\
\hline
\end{tabular}

Table 4. Exergy Flows for SSCF process

\begin{tabular}{|l|l|l|l|l|}
\hline & Pretreatment & SSCF & Neutralization & Purification \\
\hline Exergy input - Flow (MJ/h) & $562,307.89$ & $530,820.09$ & $59,077.31$ & $224,816.79$ \\
\hline Exergy output - Flow (MJ/h) & $534,659.88$ & $466,432.18$ & $54,610.83$ & $230,087.04$ \\
\hline Exergy - Q (MJ/h) output & $23,059.80$ & $2,569.24$ & 118.60 & $28,238.87$ \\
\hline Exergy - Q (MJ/h) input & $40,533.96$ & 646.78 & 0.00 & $43,488.63$ \\
\hline
\end{tabular}

irrevebilities associated with these systems. Additionally, it was observed that in the process with the technologies worked independently, greater environmental impacts can be expected taking into account that the process showed the greatest exergetic emissions among the processes evaluated. The high energy consumption associated with the catalyzed steam explosion pretreatment stage also represents a challenge for this type of processes; however, it was observed that the pretreatment stage showed lower irreversibilities and lower exergetic emissions compared to the hydrolysis and fermentation technologies. The exergy flows associated with heat transfer processes required for each stage represent an opportunity to improve the bioethanol production through the application of process integration methodologies. The design of heat exchange networks allows the reduction of global energy consumption for the simulated cases. Additionally, an integral use of the energy streams will improve the exergy efficiencies of the stages and the overall process by generating a sustainable use of the streams.

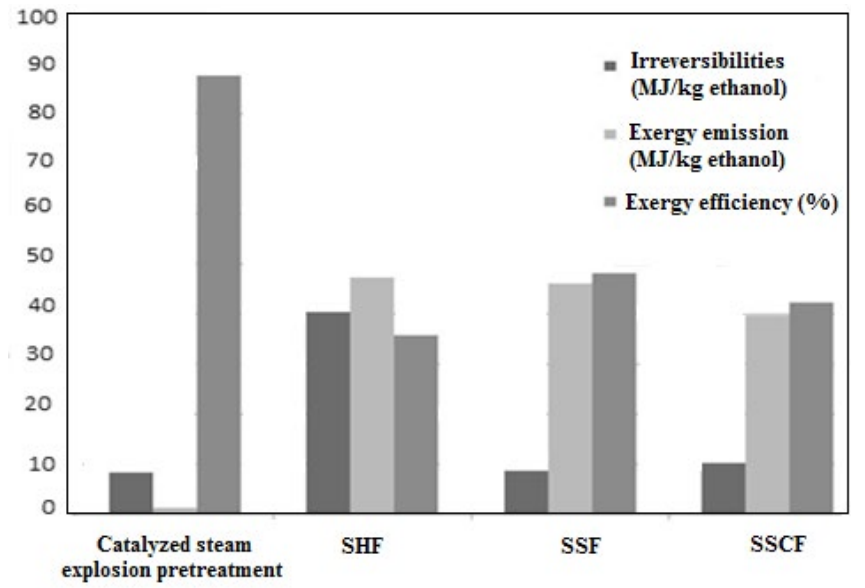

Figure 3. Exergy analysis results.

The technology using SSCF had the highest overall exergy efficiency and the lowest exergy emissions. Therefore, this alternative was selected to process integration application. Heat integration was performed for the selected case to calculate the minimum heating and cooling utilities. 
Table 5. Cold and heat streams for SSCF process

\begin{tabular}{|l|l|l|l|l|}
\hline Hot Streams & T input $\left[{ }^{\circ} \mathbf{C}\right]$ & T output $\left[{ }^{\circ} \mathbf{C}\right]$ & Enthalpy $\left[\mathbf{1 0}^{4} \mathbf{k J} / \mathbf{h}\right]$ & Flow $\left[\mathbf{1 0}^{2} \mathbf{k g} / \mathbf{h}\right]$ \\
\hline H1 & 168.33 & 25.00 & 225 & 8.36 \\
\hline H2 & 119.72 & 50.00 & 56.3 & 75.8 \\
\hline H4 & 113.73 & 40.00 & 135 & 6.01 \\
\hline H5 & 168.33 & 41.00 & 5.73 & 45.4 \\
\hline H6 & 150.00 & 25.00 & 690 & 61.0 \\
\hline H7 & 50.00 & 30.00 & 7.40 & 53.8 \\
\hline H8 & 93.21 & 26.67 & 2,500 & 937 \\
\hline H9 & 167.22 & 25.00 & 12,600 & 469 \\
\hline H10 & 150.00 & 98.89 & 8.21 & 8.44 \\
\hline H11 & 50.00 & 25.00 & 9.36 & 21.5 \\
\hline Cold Streams & T input $\left[{ }^{\circ} \mathbf{C}\right]$ & T output $\left[{ }^{\circ} \mathbf{C}\right]$ & Enthalpy $\left[\mathbf{1 0}^{4} \mathbf{k J} / \mathbf{h}\right]$ & 151 \\
\hline C1 & 48.81 & 62.78 & 542 & 942 \\
\hline C2 & 25.00 & 100.00 & 932 & 313 \\
\hline C3 & 77.09 & 150.00 & 88.4 & 69.4 \\
\hline C4 & 86.06 & 95.70 & 14,600 & 1,010 \\
\hline
\end{tabular}

Table 5 listed cold and heat streams considered for heat integration.

Grand composite curve in Figure 4 was generated and the pinch point was identified $\left(91-86^{\circ} \mathrm{C}\right)$. A thermal pinch diagram was constructed using a $\Delta \mathrm{T}_{\min }$ of $5^{\circ} \mathrm{C}$, therefore, the minimum requirements for heating and cooling utilities were calculated as $5.718 \times 10^{7} \mathrm{~kJ} / \mathrm{h}$ and $7.301 \times 10^{7} \mathrm{~kJ} / \mathrm{h}$, respectively. Furthermore, temperature ranges for the heating and cooling utilities were determined as $91-160$ ${ }^{\circ} \mathrm{C}$ for heating and $20-91{ }^{\circ} \mathrm{C}$ for cooling. By means of

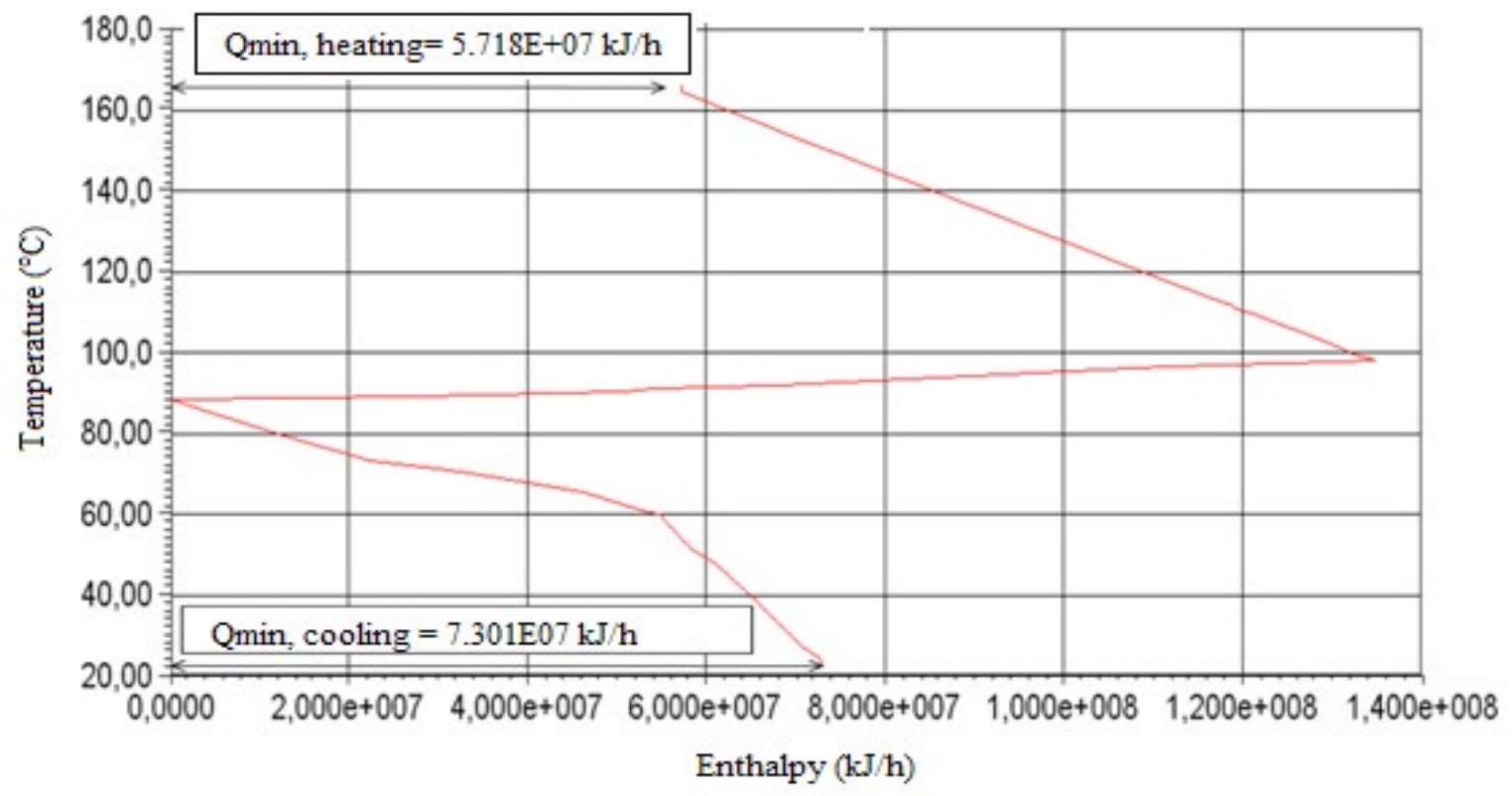

Figure 4. Grand Composite Curve - Selected Case (SSCF). 
the pinch analysis a HEN was proposed for SSCF process reducing cooling and heating utilities by $57.7 \%$ and $63.4 \%$, respectively.

\section{Conclusions}

In this work, a hierarchy approach based on exergy analysis was used to evaluate technological alternatives in bioethanol production. The bioethanol production using SHF, SSF, and SSCF showed less exergy efficiency than those obtained with catalyzed steam explosion pretreatment. Also, the exergy emissions where higher in all the hydrolysis and fermentation technologies.

For all the cases analyzed the use of SSCF technology showed a better exergy performance. However, it is necessary to evaluate integration alternatives such as mass and energy integration that allows the improvement of the sustainability parameters of the process. The HEN designed for thermal integration of the SSCF process reduced cooling and heating utilities by $57.7 \%$ and $63.4 \%$, respectively. Therefore, the improved alternative can reduce the operating cost, and enhances environmental performance for bioethanol production from lignocellulosic biomass.

\section{Acknowledgement}

The authors are thankful to University of Cartagena for providing equipment and software necessary to successfully conclude this research.

\section{References}

1. Jasman, Prijambada ID, Widianto D, Hidayat C. Increasing bioethanol yield from fermentation of sweet sorghum (Sorghum bicolor L. Moench) sap by mixed culture composed of two yeast strains. Indian Journal of Science and Technology. 2017; 10(23):1-8.

2. Sareekam N, Kamarudin SK, Kasmuri NH. Optimization of bio oil from palm oil fronds via fast pyrolysis. Indian Journal of Science and Technology. 2016; 9(21):1-13. crossref

3. Saravanan K, Duraisamy S, Ramasamy G, Kumarasamy A, Balakrishnan S. Evaluation of the saccharification and fermentation process of two different seaweeds for an eco friendly bioethanol production. Biocatalysis and Agricultural Biotechnology. 2018. In Press. crossref

4. Ravikumar S, Gokulakrishnan R, Kanagavel M, Thajuddin $\mathrm{N}$. Production of biofuel ethanol from pretreated seagrass by using Saccharomyces cerevisiae. Indian Journal of Science and Technology. 2011; 4(9):1087-9.

5. Muradovich M. Foresight of microalgae usage for the production of third-generation biofuel. Indian Journal of Science and Technology. 2017; 10(16):1-10.

6. Mohd Azhar SH, Abdulla R, Jambo SA. Yeasts in sustainable bioethanol production: A review. Biochemistry and Biophysics Reports. 2017; 10:52-61. crossref PMid:29114570 PMCid:PMC5637245

7. Akram F, Haq I ul, Imran W, Mukhtar H. Insight perspectives of thermostable endoglucanases for bioethanol production: A review. Renewable Energy. 2018; 122:22538. crossref

8. Silva JOEV, Almeida MF, Alvim-Ferraz MDC, Dias JM. Integrated production of biodiesel and bioethanol from sweet potato. Renewable Energy. 2018 Aug; 124:114-20.

9. Singh P, Singh A. Production of liquid biofuels from renewable resources. Progress in Energy and Combustion Science. 2011; 37(1):52-68. crossref

10. Aditiya HB, Mahlia TMI, Chong WT, Nur H, Sebayang AH. Second generation bioethanol production: A critical review. Renewable and Sustainable Energy Reviews. 2016; 66:631-53. crossref

11. Cardona C, Sánchez O. Fuel ethanol production: Process design trends and integration opportunities. Bioresource Technology. 2007; 98(12):2415-57. crossref. PMid:17336061

12. Berthiaume R, Bouchard C, Rosen M. Exergetic evaluation of the renewability of biofuel. Exergy, An International Journal. 2001; 1(4):256-68.

13. Yang Q, Chen B, Ji X, He Y, Chen G. Exergetic evaluation of corn-ethanol production in China. Communications in Nonlinear Science and Numerical Simulation. 2009; 14(5):2450-61. crossref

14. Velásquez $H$, Ruiz $A$, Oliveira $S$. Ethanol production from banana fruit and its lignocellulosic residues: Exergy and renewability analysis. International Journal of Thermodynamics. 2009; 12(3):155-62.

15. Tan H, Lee K, Mohamed A. Second-Generation Bioethanol (SGB) from Malaysian palm empty fruit bunch: Energy and exergy analyses. Bioresource Technology. 2010; 101(14):5719-27. crossref. PMid:20223656

16. Ojeda K, Kafarov V. Exergy analysis of enzymatic hydrolysis reactors for transformation of lignocellulosic biomass to bioethanol. Chemical Engineering Journal. 2009; 154(1/3):390-5. crossref

17. Ojeda K, Sánchez E, El-Halwagi M, Kafarov V. Exergy analysis and process integration of bioethanol production from acid pre-treated biomass: Comparison of SHF, SSF and SSCF pathways. Chemical Engineering Journal. 2011; 176:195-201. crossref 
18. Ojeda K, Sánchez E, Kafarov V. Sustainable ethanol production from lignocellulosic biomass - Application of exergy analysis. Energy. 2011; 36(4):2119-28. crossref

19. Ojeda K, Sánchez E, Suarez J, Ávila O, El-Halwagi M, Kafarov V. Application of computer-aided process engineering and exergy analysis to evaluate different routes of biofuels production from lignocellulosic biomass. Industrial \& Engineering Chemistry Research. 2011; 50(5):2768-72. crossref
20. Hamelinck C, G.Hooijdonk, Faaij A. Ethanol from lignocellulosic biomass: Techno-economic performance in short, middle- and long-term. Biomass and Bioenergy. 2005; 28(4):384-410. crossref

21. Wooley R, Ruth M, Glassner D, Sheehan J. Process design and costing of bioethanol technology: A tool for determining the status and direction of research and development. Biotechnology Progress. 1999; 15(5):794-803. crossref. PMid:10514249 